\title{
CONTRATAÇÃO, CARREIRA, VENCIMENTO E JORNADA DOS PROFISSIONAIS DA EDUCAÇÃO ESTADUAL PAULISTA (1995-2018)
}

\author{
ANDREZA BARBOSA ${ }^{1}$ \\ Márcia Aparecida Jacomini ${ }^{2}$ \\ Maria José da Silva Fernandes ${ }^{3}$ \\ Selma VenCO ${ }^{4}$
}

\begin{abstract}
RESUMO: O artigo examina as formas de contratação e designação, carreira, jornada e vencimentos do conjunto de profissionais da educação - docentes, professores coordenadores, diretores de escola, supervisores de ensino e funcionários - vinculados à Secretaria Estadual de Educação de São Paulo no período compreendido entre 1995 e 2018. Com base em ampla pesquisa documental e análise de dados estatísticos, constata-se forte adesão, nos diversos mandatos, aos valores intrínsecos à Nova Gestão Pública, que, coadunados às práticas empresariais, promoveram flexibilização nas relações de trabalho, reconfigurando o trabalho educativo e descumprindo leis nacionais, a exemplo da Lei do Piso Salarial Nacional do Magistério.
\end{abstract}

Palavras-chave: Política educacional. Condições de trabalho. Contrato de trabalho. Rede estadual de ensino de São Paulo. Nova Gestão Pública.

\section{HIRING, CAREER, SALARY, AND WORKING HOURS FOR EDUCATION PROFESSIONALS IN SÃO PAULO STATE (1995-2018)}

\begin{abstract}
The article examines forms of hiring and designation, career, working hours, and salaries of the education professionals' group - teachers, coordinating teachers, school principals, teaching supervisors, and administration fonctionnaires - linked to the São Paulo State Department of Education in the period between 1995 to 2018. Based on extensive documentary research and analysis of statistical data, it's possible to verify a strong adherence, in the various mandates, to the intrinsic values of the New Public Management, which, according with business practices, promoted flexibility in labor relations, reconfiguring educational, and not complying with national laws, such as the Law on the National Teaching Salary Floor.
\end{abstract}

Keywords: Educational politics. Work conditions. Employment contract. State education of São Paulo. New Public Management.

Este artigo foi produzido com base nos dados da pesquisa "Política Educacional na Rede Estadual Paulista (1995-2018)", financiada pela Fundação de Amparo à Pesquisa do Estado de São Paulo (Fapesp), Processo 2018/09983-0.

1.Universidade de Sorocaba - Programa de Pós-graduação em Educação - Sorocaba (SP), Brasil. E-mail: andrezab27@gmail.com

2.Universidade Federal de São Paulo - Escola de Filosofia, Letras e Ciências Humanas - Departamento de Educação - Guarulhos (SP), Brasil. E-mail: jacominimarcia@gmail.com

3.Universidade Estadual Paulista - Faculdade de Ciências - Departamento de Educação - Bauru (SP), Brasil. E-mail: mj.fernandes@unesp.br 4.Universidade Estadual de Campinas - Faculdade de Educação - Departamento de Políticas, Administração e Sistemas Educacionais - Campinas (SP), Brasil. E-mail: svenco@unicamp.br

Editora de Seção: Adriana Dragone Silveira 


\title{
CONTRATACIÓN, CARRERA, SALARIO Y JORNADA DE LOS PROFESIONALES DE LA EDUCACIÓN DEL ESTADO DE SÃO PAULO (1995-2018)
}

\begin{abstract}
RESUMEN: El artículo examina las formas de contratación y asignación, carrera, jornada y salario del conjunto de profesionales de la educación - docentes, docentes coordinadores, directores de escuela, supervisores docentes y empleados - vinculados a la Secretaría de Educación del Estado de São Paulo en el período 1995 al 2018. A partir de una extensa investigación documental y análisis de datos estadísticos, existe un fuerte apego, en los distintos mandatos, a los valores intrínsecos a la Nueva Gestión Pública, que, en línea con las prácticas empresariales, promovieron la flexibilidad en las relaciones laborales, reconfigurando la labor educativa y no cumpliendo con las leyes nacionales, como la Ley sobre el Piso Salarial Nacional de Maestros
\end{abstract}

Palabras-clave: Política educativa. Condiciones de trabajo. Contrato de trabajo. Educación del estado de São Paulo. Nueva Administración Pública.

\section{Introdução}

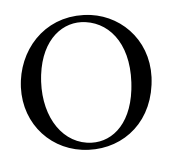

presente artigo se inscreve no âmbito de pesquisa mais ampla, cujo objetivo central foi analisar as diversas dimensões da política educacional da Secretaria Estadual de Educação de São Paulo $(\text { SEE-SP })^{1}$ no período de 1995 a 2018. A grandeza dessa rede dá ideia de sua importância, tanto pelo número de matrículas, como pela quantidade de profissionais. Em 2018, eram 3.548.988² estudantes de educação infantil, Ensino Fundamental, Ensino Médio, educação especial e educação de jovens e adultos matriculados em $5.374^{3}$ escolas; e um total de 249.050 profissionais da educação, distribuídos em cinco segmentos: $190.396^{4}$ docentes, $44.398^{5}$ funcionários de escola, $7.601^{6}$ professores coordenadores, $5.051^{7}$ diretores e $1.604^{8}$ supervisores de ensino.

O recorte de análise volta-se à investigação dos marcos legais e dados estatísticos concernentes às características das carreiras e aos elementos a ela intrínsecos, referentes aos cinco segmentos profissionais da educação com vinculação direta às escolas: professores, supervisores de ensino, diretores de escola, professores coordenadores e Quadro de Apoio Escolar (QAE).

Tendo em vista que cargos, funções e suas terminologias são distintos nos sistemas de ensino, faz-se necessário esclarecer que, na rede paulista, o supervisor desenvolve seu trabalho nas Diretorias de Ensino e compete ao cargo, sinteticamente, fiscalizar práticas e procedimentos administrativos nas escolas, conforme legislações educacionais nacional e estadual, além de acompanhar e orientar as propostas pedagógicas, em consonância com ordenamento da pasta. Já a função de professor coordenador (PC) cabe a um docente designado cujo papel é orientar e coordenar o desenvolvimento da política educacional na escola, especialmente nos aspectos pedagógicos, enquanto os profissionais do QAE realizam as atividades de secretaria escolar, acompanhamento dos estudantes nos momentos em que não estão com atividades executadas pelos professores, atividades de limpeza, merenda e vigilância.

O delineamento temporal é marcado por sucessivas e ininterruptas gestões de um mesmo partido político, o Partido da Social Democracia Brasileira (PSDB), o qual levou a cabo amplas medidas educacionais que reordenaram a organização pedagógica e administrativa da rede pública estadual. Tais medidas não ocorreram aleatória e despretensiosamente. Pelo contrário: desde o primeiro comunicado 
da SEE-SP, de 22 de março de 1995 (SÃO PAULO, 1995), às ações postas em prática até o final de 2018, no decurso de seis gestões, identificou-se confluência diante de um projeto educacional balizado pela Nova Gestão Pública (NGP).

A pesquisa de caráter documental inventariou leis, decretos e portarias, entre outros documentos produzidos pela SEE-SP, pelo Conselho Estadual de Educação (CEE-SP) e pela Assembleia Legislativa do Estado de São Paulo (Alesp). Os dados estatísticos foram obtidos sob demanda ao Sistema de Informação ao Cidadão (SIC). Todavia, as séries históricas têm comprometimentos, dadas as lacunas no registro e na organização dos dados por parte da SEE-SP ou mesmo a ausência de informações no início do período analisado. Nesse sentido, o estudo traz uma abordagem inédita no que se refere à análise articulada da legislação que regulamenta o trabalho dos profissionais da educação num período amplo, permitindo compreender os sentidos das mudanças empreendidas.

Dessa forma, a pesquisa, na dimensão aqui abordada, visa contribuir tanto para a ampliação de estudos sobre as relações e condições trabalhos dos profissionais da educação (MONLEVADE, 2000; GATTI; BARRETO, 2009; BASSI; FERNANDES; ROLIM, 2018) quanto para a análise das políticas públicas educacionais e seus desdobramentos para os servidores públicos.

$\mathrm{O}$ artigo estrutura-se em duas seções: na primeira, discutem-se os pressupostos da NGP e suas expressões na legislação relativa às relações de trabalho e aos possíveis desdobramentos nas condições de trabalho; na segunda, apresentam-se as reconfigurações de carreiras, vencimentos e jornadas de trabalho dos segmentos profissionais. Finaliza-se o texto problematizando os limites à valorização dos profissionais da educação pelo governo paulista.

\section{Implicações da Nova Gestão Pública para o Trabalho Educacional}

O ano de 1995 marcou as políticas educacionais na rede estadual de ensino de São Paulo. Em confluência com o governo federal, no momento representado pelo Presidente Fernando Henrique Cardoso, o estado de São Paulo inaugurou uma série de transformações pautadas pelo Plano Diretor da Reforma do Aparelho do Estado (BRASIL, 1995), que trazia em seu bojo o discurso da modernização e do enxugamento da máquina pública, tendo como base a privatização e a terceirização. De forma geral, a NGP introduziu no serviço público as orientações de cunho gerencialista, advindas dos setores empresarial e financeiro.

A Reforma do Estado e suas medidas imprimiram uma nova racionalidade política e econômica em diferentes partes do mundo a partir da década de 1980. De acordo com Verger e Normand (2015), a NGP não implica a retirada do Estado dos serviços públicos, mas recontextualiza as funções governamentais, distanciando-o do caráter provedor para centrar-se na regulação, na avaliação e na distribuição de incentivos. Para os autores, há uma conotação em prol do mercado e uma suposta defesa da eficiência do setor público combinada com austeridade fiscal, que apresenta diferentes clivagens em razão das traduções e hibridizações locais na aplicação da NGP, fruto de fatores históricos e culturais (VERGER; NORMAND, 2015). Independentemente da forma como se revestiu, a NGP provocou significativas alterações na ordenação da sociedade, impactando os setores públicos em distintos países.

Em que pese a força internacional da NGP, é necessário considerar também as distintas formas de incorporação de seus princípios no âmbito dos estados, nos quais interfere a regulação exercida pelos atores sociais e, nesse caso, destacam-se as formas de resistência que se dão por trilhas distintas, seja pela atuação sindical, seja por maior ou menor mobilização e participação das comunidades e dos profissionais 
no cotidiano escolar, ou ainda pelas críticas de integrantes do próprio governo. Interfere, também, no grau de recepção ou negação das medidas, o tipo de medida envolvida na implementação de uma proposta. A título de exemplo, a terceirização das atividades pode ser mais intensa numa dada área do serviço público e menos provável, em virtude da natureza e da especificidade do trabalho, em outras. Dessa forma, arranjos e rearranjos são realizados nos estados, dando à NGP um aspecto heterogêneo.

Ao longo dos 24 anos de governo paulista analisados na pesquisa, houve avanços e recuos em relação a vários programas e projetos. No período, algumas medidas evoluíram a olho nu, devido ao seu grau de mudança e explicitação de objetivos; outras, embora não tão visíveis e imediatas, não foram menos importantes na consolidação da política. Como um rio de drenagem meândrica, ${ }^{9}$ a NGP espraia-se em alguns pontos, recua em outros e faz muitos contornos; cria braços descontínuos e subparalelos, chegando até a parecer afastar-se de sua calha original, mas, ao final, não abandona seu curso principal de drenagem, que segue sendo pautado pelo gerencialismo.

No caso da educação, alguns momentos foram de recrudescimento das medidas gerenciais, como observado na primeira gestão (1995-1998) e na ocorrida entre 2007 a 2010. Entretanto, os períodos intermediários e posteriores a esses não romperam com o modelo, mas deram continuidade e coerência aos princípios da NGP, garantindo seu aprofundamento, que se deu por meio de aspectos abordados por distintos autores, quando da análise de outros contextos educacionais que aqui se reproduziram, tais como: fortalecimento do caráter regulador, avaliador e distribuidor de incentivos por meio de bonificação; ênfase na responsabilidade individual e no novo profissionalismo (VERGER; NORMAND, 2015); transferência do locus de controle da gestão para os trabalhadores expostos a relações contraditórias de cooperaçãocompetição; ampliação das possibilidades de inserção do setor privado nas atividades de gestão e ensino (HALL; GUNTER, 2015); declínio da isonomia e apogeu da equidade (SHIROMA, 2006); novos modelos de profissionalização baseados no ideário da gestão para resultados (CAMPOS, 2004); centralidade na avaliação externa como eixo fundante do trabalho (OLIVEIRA; DUARTE; CLEMENTINO, 2017); e centralização dos conteúdos por meio de um currículo oficial avaliado por meio de testes estandardizados (HALL; GUNTER, 2015).

\section{Reconfiguração do Trabalho Educativo no Âmbito da Nova Gestão Pública}

Os profissionais da educação vinculados à SEE-SP são divididos em Quadro do Magistério (QM) e QAE. Segundo a Lei Complementar n. 836/1997 (SÃO PAULO, 1997), que instituiu o Plano de Carreira, Vencimentos e Salários para o QM, esse grupo é formado pela classe docente, constituída por Professor de Educação Básica I (PEB I) - que atua nos anos iniciais do Ensino Fundamental - e Professor de Educação Básica II (PEB II) - nos anos finais do Ensino Fundamental e no Ensino Médio. Também se constitui pelas classes de suporte pedagógico: diretor de escola; supervisor de ensino; e dirigente regional de ensino. Em conformidade com a mesma lei, os professores ainda podem exercer a função designada de vice-diretor de escola e PC.

No que diz respeito às formas de contratação, chama atenção a regularização da prática de admissão de profissionais da educação temporários, por meio de processos seletivos e a não efetivação via concursos públicos, como prevê a legislação federal (BRASIL, 1996).

Em relação aos professores, maior grupo profissional da rede, assevera-se que, no período, a excepcionalidade presente na legislação constituiu prática recorrente em São Paulo, atingindo o patamar de 72,87\% de professores não efetivos em 1999, conforme observado na Fig. 1. 


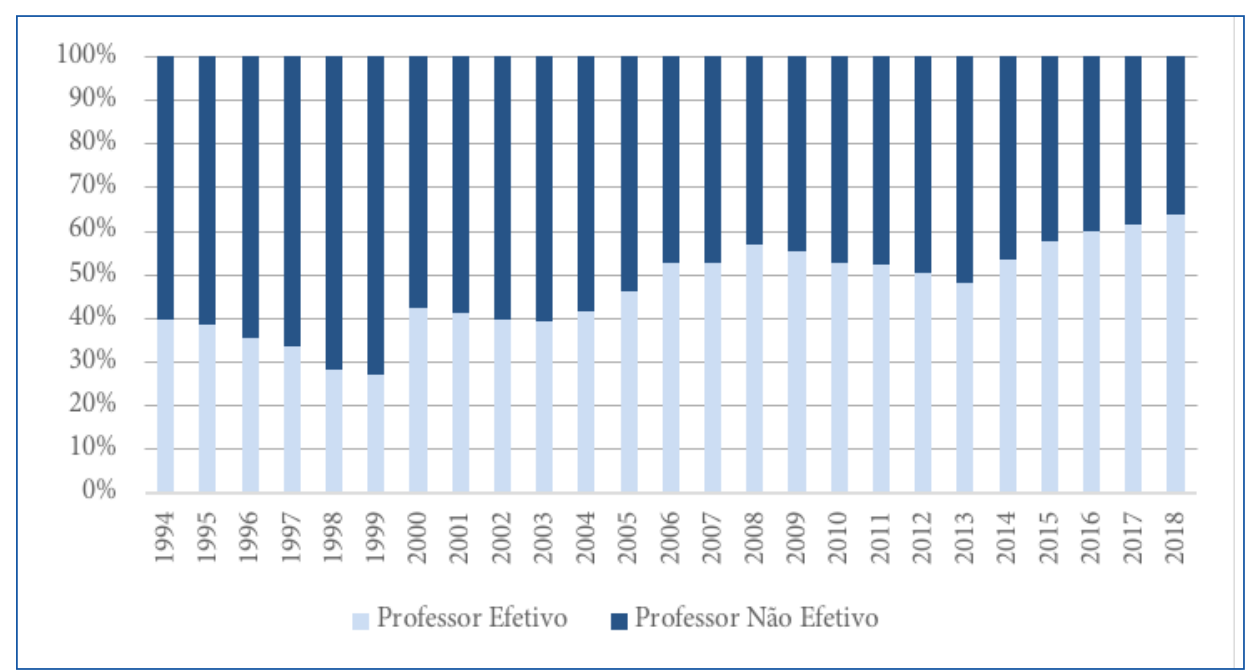

Fonte: Elaboração própria, com base em dados do Boletim de Acompanhamento de Pessoal da SEE-SP (Prodesp), de 1994 a 1998, e da Coordenadoria de Gestão de Recursos Humanos (CGRH), de 1999 a 2018.

Figura 1. Distribuição de professores efetivos e não efetivos; rede estadual paulista - 1994 a 2018 (mês de referência: novembro) (\%)

A despeito da redução da quantidade de professores não efetivos (Fig. 2), cabe observar que a elevação do número de professores efetivos é inferior à diminuição de docentes não concursados. Há, ainda, a redução de mais de 60 mil docentes nos últimos cinco anos, sendo que, desses, mais de 40 mil eram temporários.

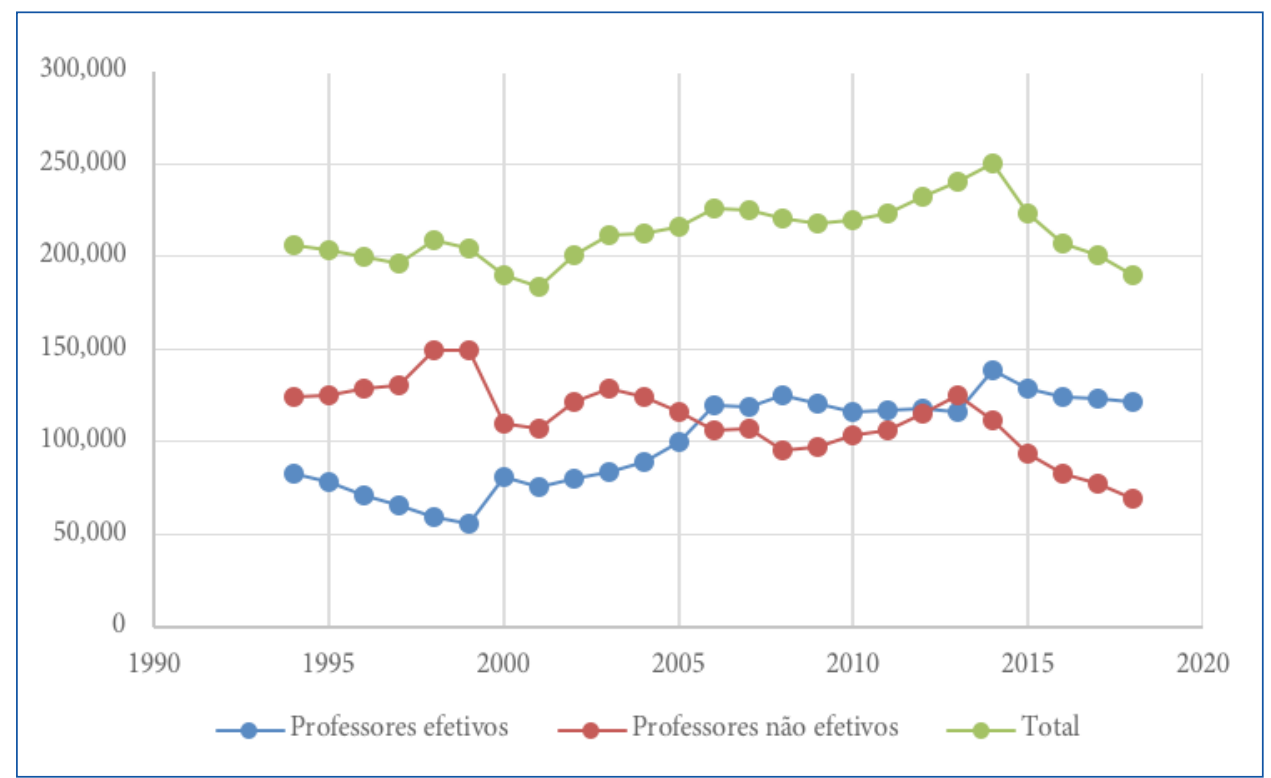

Fonte: Elaboração própria com base em dados do Boletim de Acompanhamento de Pessoal da SEE-SP (Prodesp), de 1994 a 1998, e da Coordenadoria de Gestão de Recursos Humanos (CGRH), de 1999 a 2018.

Figura 2. Distribuição de professores efetivos e não efetivos; rede estadual paulista - 1994 a 2018 (mês de referência: novembro) (n. abs.)

Portanto, se a relação entre os professores efetivos e não efetivos melhorou não foi necessariamente em decorrência do aumento do número de professores concursados, mas da redução no número total de docentes na rede, que se deu de forma mais acentuada entre os não efetivos. Essa redução foi mais expressiva entre os PEB I. 
A Tabela 1 mostra que, em 1998, após a aprovação do Fundef, os PEB I correspondiam a 48,5\% do total de docentes da rede e, no fim do período, em 2018, representavam 21,4\%. Além disso, nos 24 anos analisados pela pesquisa, ocorreram somente dois concursos públicos para esse segmento: em 2005 e em 2014. Esses dados apontam significativa redução da cobertura de atendimento da rede pública estadual nos anos iniciais do Ensino Fundamental, a qual foi marcada pela transferência de responsabilidades aos municípios.

Tabela 1. Professores da educação básica por classes docentes; rede estadual paulista - 1998 a 2018 (mês de referência: novembro) (n. abs.)

\begin{tabular}{|c|c|c|c|}
\hline \multirow{2}{*}{ Ano } & \multicolumn{3}{|c|}{ Classes docentes } \\
\hline & PEB I & PEB II & TOTAL \\
\hline 1998 & 94.913 & 100.616 & 195.529 \\
\hline 1999 & 102.943 & 105.900 & 208.843 \\
\hline 2000 & 73.098 & 117.115 & 190.213 \\
\hline 2001 & 63.222 & 119.905 & 183.127 \\
\hline 2002 & 68.626 & 131.909 & 200.535 \\
\hline 2003 & 70.015 & 141.851 & 211.866 \\
\hline 2004 & 65.194 & 147.318 & 212.512 \\
\hline 2005 & 63.206 & 153.140 & 216.346 \\
\hline 2006 & 64.093 & 161.463 & 225.556 \\
\hline 2007 & 63.000 & 162.085 & 225.085 \\
\hline 2008 & 57.478 & 163.098 & 220.576 \\
\hline 2009 & 55.805 & 162.422 & 218.227 \\
\hline 2010 & 55.869 & 163.869 & 219.738 \\
\hline 2011 & 56.982 & 166.158 & 223.140 \\
\hline 2012 & 63.039 & 169.689 & 232.728 \\
\hline 2013 & 68.893 & 171.885 & 240.778 \\
\hline 2014 & 64.178 & 186.514 & 250.692 \\
\hline 2015 & 52.531 & 170.560 & 223.091 \\
\hline 2016 & 48.323 & 158.482 & 206.805 \\
\hline 2017 & 43.197 & 154.549 & 197.746 \\
\hline 2018 & 40.867 & 149.529 & 190.396 \\
\hline
\end{tabular}

Fonte: Elaboração própria com base nos dados fornecidos pela SEE-SP via SIC (Protocolo SIC-SP n. 444191922700).

Entre os professores, pode ocorrer a designação para desempenhar a função de PC. Observa-se, na Fig. 3, que, após aparente estabilidade, houve destacado aumento no número de designações para a função entre 2007 e 2014, período que corresponde à implementação do currículo oficial e ao aprimoramento das formas de controle dos resultados por desempenho. A partir de então, porém, há declínio acentuado do número de $\mathrm{PC}$, com retorno aos patamares iniciais da série histórica.

Entre os supervisores de ensino e os diretores de escola, que também compõem o QM, a admissão de profissionais não efetivos, por meio de designação, foi prática habitual, destacando-se a presença de diretores concursados exercendo temporariamente a função de supervisor nas Diretorias de Ensino, especialmente a partir de 2010, conforme se demonstra na Fig. $4 .^{10}$

Tal prática desdobra-se em ao menos duas severas situações. De um lado, a designação para ocupar o cargo de supervisor de ensino, usualmente por um diretor concursado, exige a presença de um professor para 


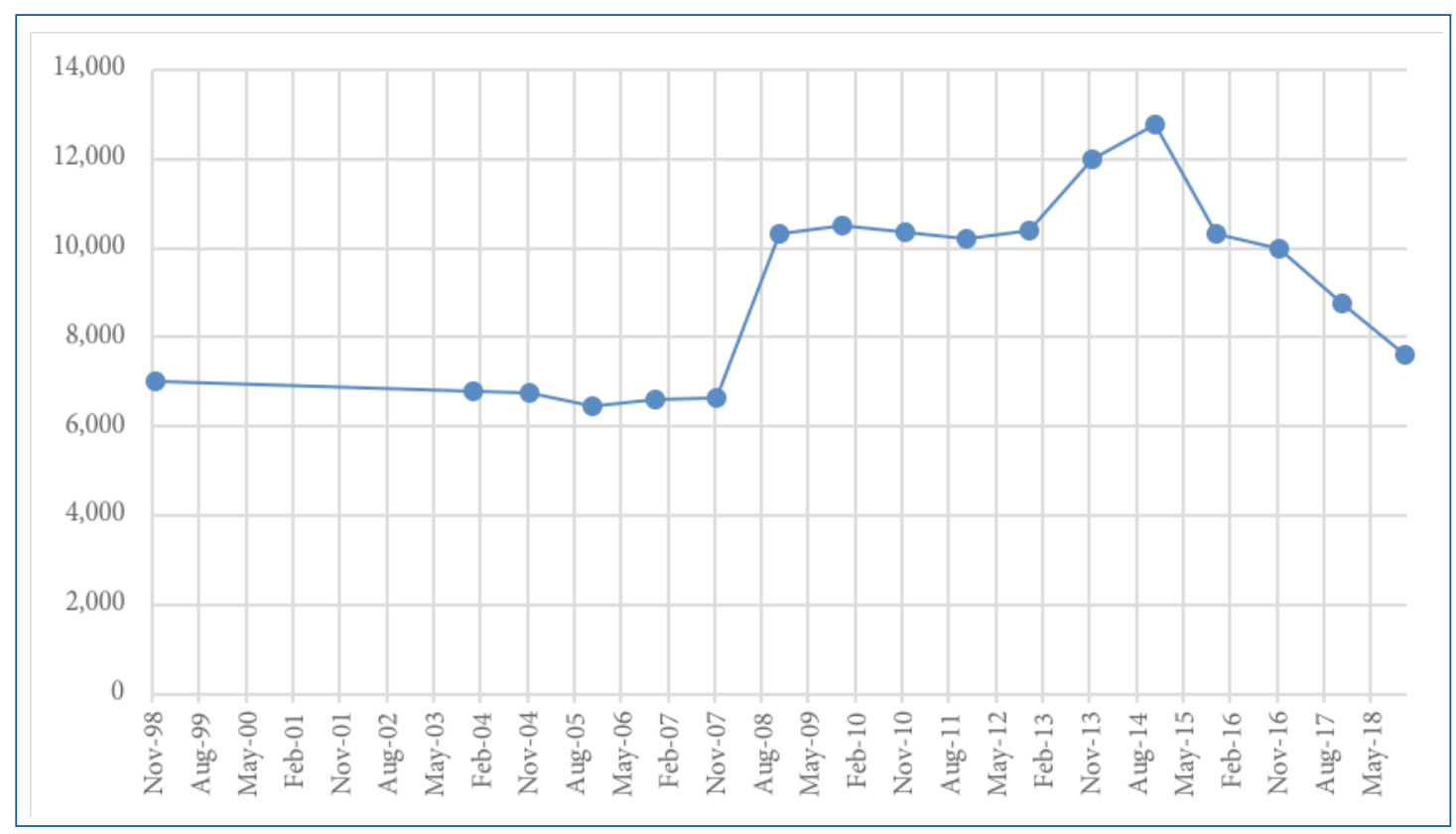

Fonte: Elaboração própria com base nos dados fornecidos pela SEE-SP via SIC (Protocolo SIC-SP n. 667431915807).

Figura 3. Distribuição de professores coordenadores; rede estadual paulista - 1998 a 2018 (mês de referência: novembro) (n. abs.)

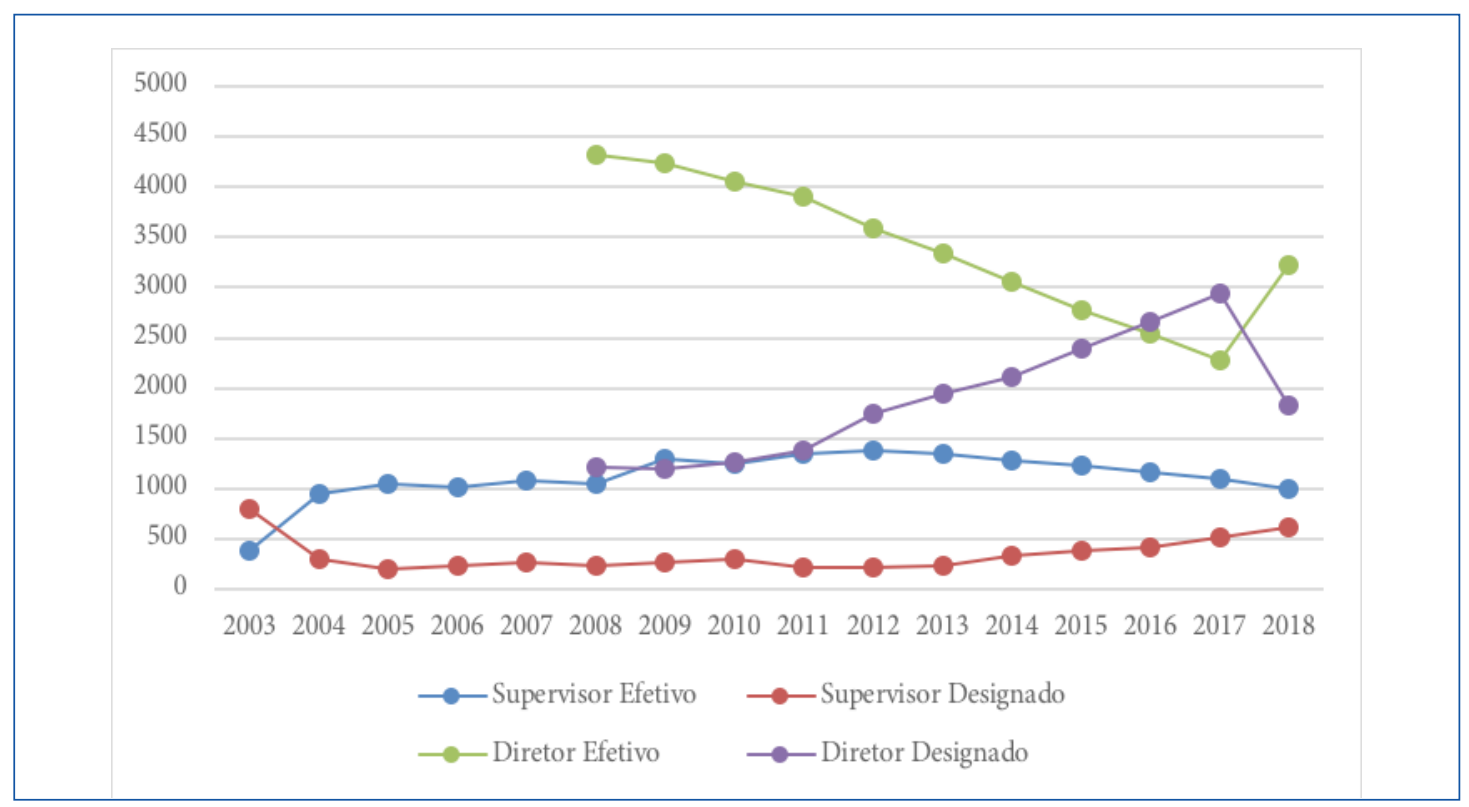

Fonte: Elaboração própria com base nos dados fornecidos pela SEE-SP via SIC (Protocolos SIC-SP n. 588911912029 e n. 588911912020 ).

Figura 4. Distribuição dos supervisores de ensino (2003 a 2018) e diretores de escola efetivos e designados (2008 a 2018); rede estadual paulista (n. abs.)

substituir a direção vacante, concretizando um processo de precariedade em cascata (VENCO; SANCHEZ, 2021), o qual desagua na contratação temporária de outros professores. Isso representa importante redução de custos à SEE-SP, uma vez que os professores contratados contam com direitos significativamente diferenciados dos efetivos. Por outro lado, pondera-se que o provimento do cargo de supervisor por um profissional do magistério designado temporariamente tende a limitar sua autonomia na realização de suas atribuições, visto 
que a designação pode ser cessada pelo dirigente regional, com base em critérios subjetivos, numa lógica que elege supervisores e diretores como fundamentais na implementação e no controle das políticas educacionais e da gestão da escola.

Ao analisar as condições necessárias para o bom funcionamento das escolas, destacam-se os dados referentes ao QAE, que sofreu sensível redução do contingente no período de 2004 a 2018, conforme a Fig. 5.

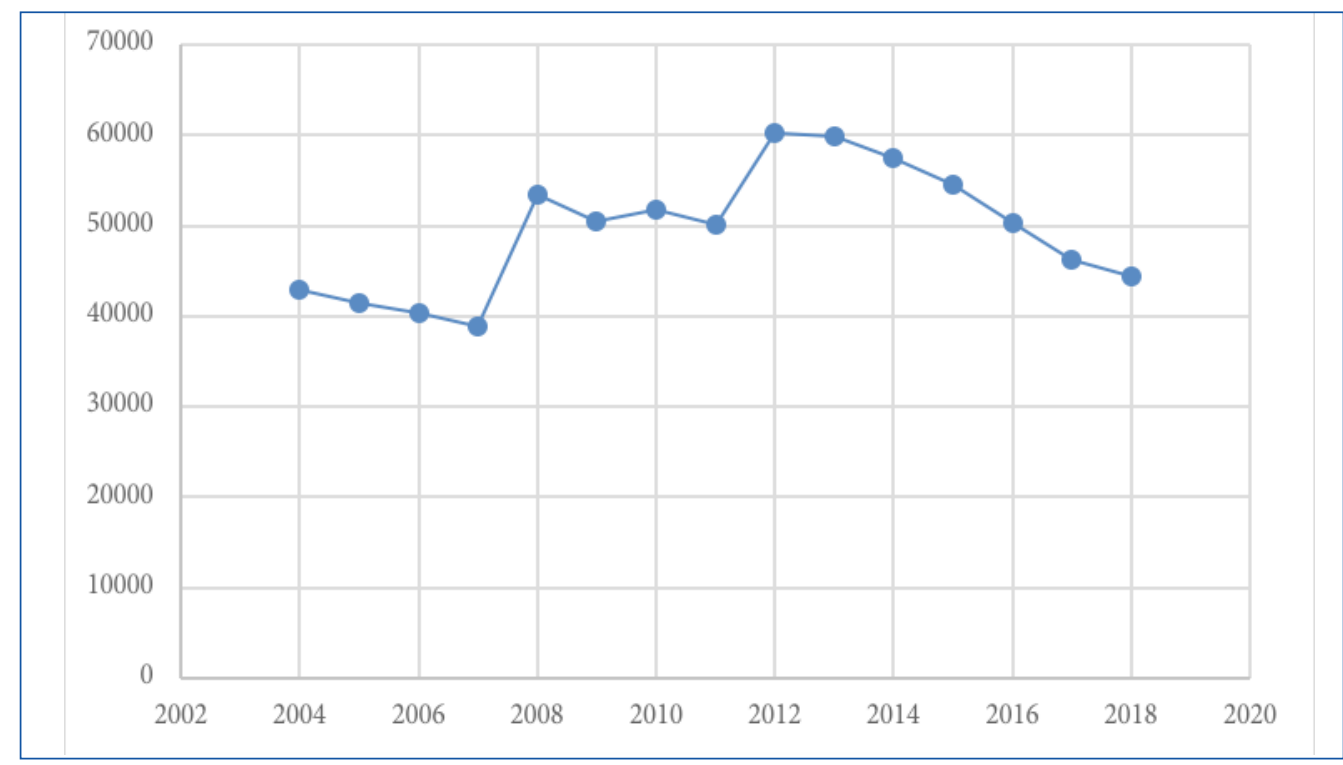

Fonte: Elaboração própria a partir dos dados fornecidos pelo Cadastro Funcional da Educação da SEE-SP.

Figura 5. Distribuição do Quadro de Apoio Escolar; rede estadual paulista - 2004-2018 (n. abs.)

A redução do tamanho da rede, representada aqui pela diminuição do contingente de profissionais do QAE e do QM, pode estar relacionada ao processo de "reorganização silenciosa" empreendido após a tentativa anunciada de reconfiguração da rede pública paulista, em 2015, a qual gerou intensa mobilização, sobretudo dos alunos (CÁSSIO et al., 2016). Mediante tal situação, o governo paulista poderia ter optado pela redução do número de estudantes por turma, criando melhores condições de trabalho para os profissionais e favorecendo as relações de ensino e de aprendizagem. Entretanto, considera-se, privilegiou a racionalização de custos em detrimento da possibilidade de melhor qualidade da educação.

Especificamente no caso do QAE, além da redução do seu contingente, observa-se o desmonte da estrutura funcional, representada por cargos previstos, conforme demonstra a Tabela 2. No início do período abarcado pela pesquisa, existiam cinco diferentes cargos e, ao fim, somente um, com denominação genérica e, portanto, sem especificidade de atividades a serem realizadas. Compreende-se, que a fusão é representativa da flexibilização e da polivalência do trabalho na rede, já que, à medida que vários cargos do QAE foram extintos, foi necessário mobilizar servidores já existentes para atuar em várias frentes.

No QAE, também merece destaque a criação da função gratificada de Gerente de Organização Escolar (GOE), instituída pela Lei Complementar n. 1.144/2011, a qual pode ser exercida pelo agente de organização escolar, pelo secretário de escola ou pelo assistente de administração escolar, estando os dois últimos cargos em extinção após o ano 2000. O GOE tem uma ampla lista de atribuições, que abrangem a gestão geral e dos recursos da escola, a formação dos outros funcionários, o gerenciamento da merenda escolar, entre outras. 
Tabela 2. Mudanças no Quadro de Apoio Escolar - 1992 a 2018

\begin{tabular}{ccc}
\hline Ano & Lei & Cargos previstos \\
& & Secretário de Escola; \\
\multirow{2}{*}{1992} & Lei Complementar n. 7698 & Servente Escola; \\
& (SÃO PAULO, 1992) & Oficial de Escola; \\
& & Assistente de Administração Escolar. \\
\hline \multirow{2}{*}{2000} & Lei Complementar n. 888 & Secretário de Escola; \\
& (SÃO PAULO, 2000) & Agente de Organização Escolar; \\
\multirow{2}{*}{2011} & Lei Complementar n. 1144 & Agente de Serviços Escolares. \\
\hline \multirow{2}{*}{2013} & (SÃO PAULO, 2011) & Agente de Serviços Escolares; \\
& Decreto n. 59.957 & Agente de Organização Escolar. \\
\hline
\end{tabular}

Fonte: Elaboração própria com base na legislação.

Aos moldes do ideário da NGP, que introduz elementos da gestão empresarial no setor público, a terceirização passou a constituir ação constante para a contratação de funcionários de escolas. Em 2008, por exemplo, foi divulgado edital para a admissão de 20 mil funcionários temporários, por meio de pregões destinados a empresas privadas. O recrutamento de agentes de serviços escolares e agentes de organização escolar para atuar na merenda, na limpeza e na inspeção das escolas deu-se sob o argumento da modernização, do aumento da eficiência dos serviços e da redução dos custos. Com tal alegação, o estado de São Paulo apostou na coexistência de funcionários com cargos em extinção e terceirizados no mesmo local de trabalho.

Ainda no que diz respeito às formas de contratação na SEE-SP, vale ressaltar a mudança empreendida a partir de 2007, com a criação de diferentes segmentos docentes, que, designados por letras, têm relações de trabalho diferenciadas, o que acarreta condições diversas ao exercício das mesmas atividades nas escolas (SANTOS, 2016; FONTANA, 2019).

No que tange à carreira dos profissionais da educação da rede pública estadual paulista, no período de 1995 a 2018, identifica-se congruência à lógica gerencialista, com evidentes mudanças. O Estatuto do Magistério Paulista, criado pela Lei Complementar n. 444/1985, considerava elementos de progressão na carreira, basicamente, o tempo de trabalho e a formação (SÃO PAULO, 1985). Com a aprovação de um novo plano, pela Lei Complementar n. 836/1997, a evolução funcional passou a considerar a via acadêmica, pautada na conclusão de cursos de Mestrado e Doutorado, e a via não acadêmica, por meio da realização de cursos de curta duração, ambas distribuídas em cinco níveis. (SÃO PAULO, 1997).

Em 2009, com a Lei Complementar n. 1.097 (SÃO PAULO, 2009b), outra mudança importante foi adotada para possibilitar a progressão dos profissionais do QM na carreira, o que passou a acontecer não apenas pelas vias supracitadas, agora organizadas em oito níveis, mas também pela aprovação em uma avaliação conhecida como Prova de Mérito (representada por oito faixas). Assim, além da ampliação de faixas e níveis, houve a introdução do critério de mérito, como forma de evolução funcional, aos moldes dos princípios gerencialistas de gestão.

A maior amplitude da carreira e os valores de vencimentos previstos para os estágios mais avançados podem causar equivocadamente a impressão de uma rede que valoriza os esforços dos docentes e premia os que mais se destacam. No entanto, a análise do regramento e da distribuição dos profissionais revela verdadeiros entraves para avançar na carreira, na passagem de um nível a outro e, principalmente, de uma faixa a outra, dificultando alçar estágios mais elevados e, consequentemente, melhores vencimentos. A distribuição de professores por faixa/nível (Fig. 6) evidencia a dificuldade de progredir na carreira num contexto de valorização da meritocracia. 


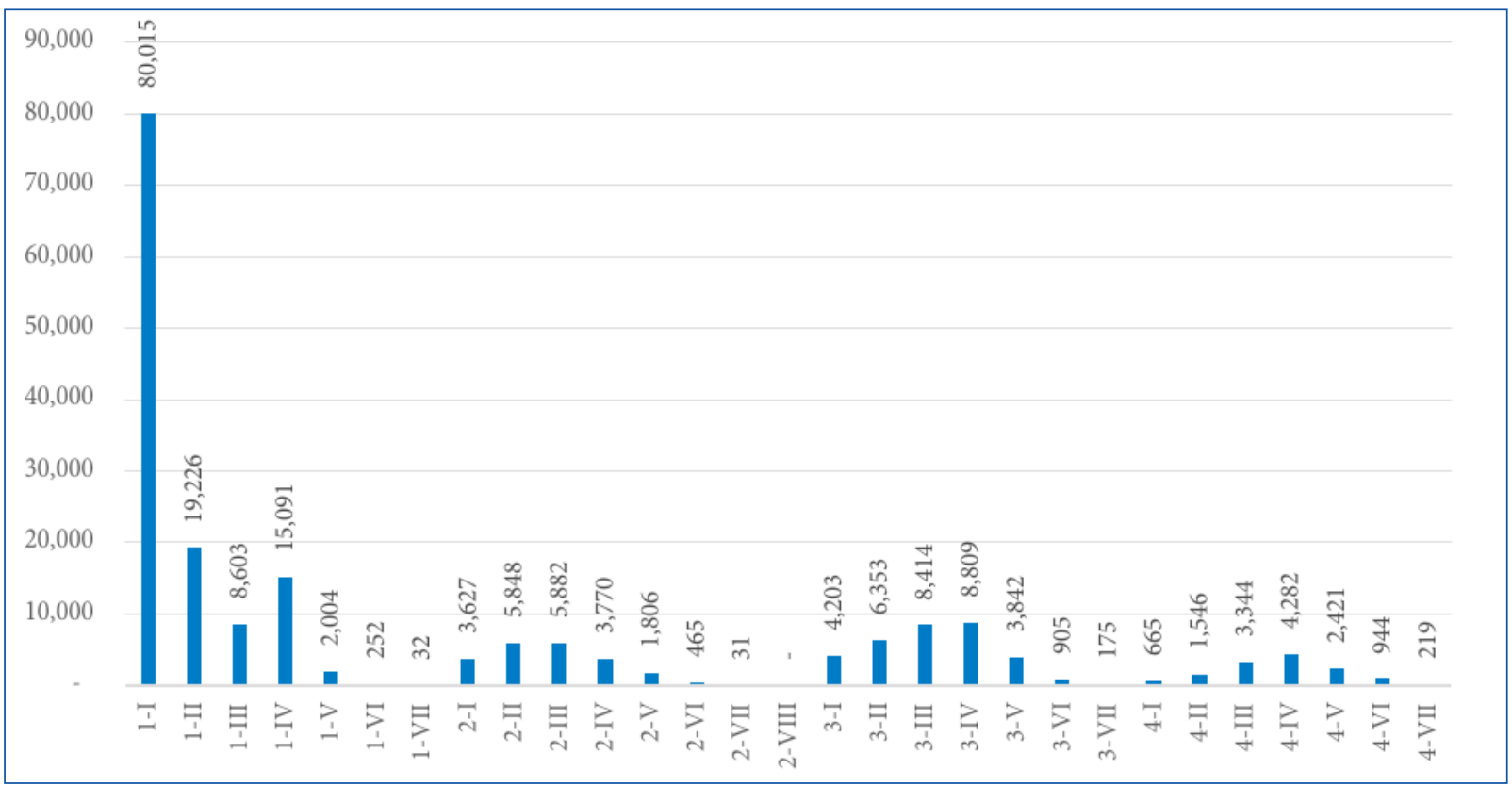

Fonte: BARBOSA et al., 2020, p. 800.

Figura 6. Distribuição de professores por faixa/nível da carreira; rede estadual paulista - 30 nov. 2018 (n. abs.)

Considera-se, no presente artigo, que uma estrutura dificultadora da progressão na carreira contribui para torná-la pouco atrativa, sobretudo porque os vencimentos fixados para ingressantes são muito baixos. A Lei Complementar n. 1.317/2018 (SÃO PAULO, 2018a), ainda em vigor, fixou os valores sobre os vencimentos iniciais e finais dos docentes por uma jornada de 40 horas semanais, sendo $\mathrm{R} \$ 2.233,02$ para o PEB I em início de carreira (faixa I, nível 1) e R\$2.585,01 para o PEB II. Visto que quase metade dos professores da rede se encontra nesse estágio inicial da carreira, conforme a Fig. 6, apreende-se quão mal-remunerados são os professores paulistas. Nesse sentido, vale ressaltar que os vencimentos do PEB I estão, desde 2014, abaixo do mínimo previsto na Lei n. 11.738 (BRASIL, 2008), que estabeleceu o Piso Salarial Profissional Nacional (PSPN). Em 2020, o vencimento do PEB II também passou a estar abaixo do mínimo estabelecido por essa lei, no valor de R $2.886,24$. Destaca-se, ainda, que a formação exigida para esse profissional na rede estadual paulista é de educação superior, ao passo que o piso se refere a profissionais com formação em Ensino Médio, o que torna mais grave a comparação.

A evolução dos vencimentos corrigidos ao longo do período de 1995 a 2018 mostra que os vencimentos iniciais do PEB I tiveram um crescimento de 220,9\% e, do PEB II, de 226,8\%, ao passo que a inflação registrada no período foi de $322,3 \%,{ }^{11}$ o que indica uma redução significativa do poder aquisitivo dos professores num dos estados do país com maior custo de vida.

Outro importante parâmetro de comparação para analisar a remuneração dos profissionais da educação é o Salário Mínimo Necessário (SMN), calculado pelo Departamento Intersindical de Estatística e Estudos Socioeconômicos (Dieese), o qual representa o mínimo necessário para a sobrevivência de uma família de quatro pessoas, conforme direitos estabelecidos na Constituição Federal de 1988 (BRASIL, 1988). Em dezembro de 2018, o SMN do Dieese correspondia a R \$3.960,57, enquanto, conforme Lei Complementar n. 1317/2018 (SÃO PAULO, 2018a), o vencimento-base do supervisor de ensino era de R\$3.356,59; do diretor de escola, de R \$ 2.939,40; do PEB I, de R \$ 2.233,02; e do PEB II, de R $2.585,0$. O vencimento-base dos profissionais da Classe de Apoio Escolar, ligada ao QAE, na estrutura 1 era de R\$ 836,06; na estrutura 2, de R 1.005,79; e na estrutura 3 (classes em extinção), de R \$ 1.357,83. Ou seja, o vencimento-base dos cinco segmentos aqui analisados não correspondia ao valor do SMN calculado pelo Dieese. 
No caso dos professores, especificamente, reafirma-se que a desvalorização salarial se vincula à atratividade do magistério na rede paulista no período analisado (MONLEVADE, 2000; GATTI et al., 2010), ratificada pelos dados referentes às exonerações. A média de exonerações entre 1997 e 2018 foi de 2.030 ao ano, portanto, superior a dez solicitações por dia letivo. Constata-se o crescimento do abandono da docência na rede, cuja média, entre 1997 e 2007, foi de 1.269 exonerações/ano, praticamente dobrando de 2008 a 2018, quando atinge 2.846 por ano.

A distribuição do tempo médio de exercício docente na rede, tendo como base a aquisição de quinquênios após a permanência no cargo por 1.825 dias, ou cinco anos, indica percentual considerável de professores com pouco tempo de trabalho na SEE-SP. Em novembro de 2018, 32,4\% dos docentes ativos ainda não tinham completado nenhum quinquênio, sendo possível conjecturar que esse grupo, diante de frágeis condições de trabalho, especialmente quanto aos vencimentos, é mais vulnerável à exoneração.

A pesquisa de Pagani (2019), ao analisar as exonerações de docentes na rede pública estadual paulista, sinaliza que o abandono definitivo do magistério geralmente é precedido por afastamentos temporários, sinalizados por faltas ou licenças médicas, o que, segundo a autora, caracteriza um processo de ruptura gradual com o serviço público. A Tabela 3 destaca o número de licenças médicas concedidas a professores (PEB I e II) no período de 2014 a 2018, dando pistas para a definição de políticas de permanência docente.

Tabela 3. Quantidade de licenças médicas concedidas para professor (PEBs I e II), por ano - $2014^{12}$ a 2018 (n. Abs.)

\begin{tabular}{cccccc}
\hline $\begin{array}{c}\text { Motivo da licença de acordo com o Código } \\
\text { Internacional de Doenças (CID) 10 }\end{array}$ & $\mathbf{5}$ Quantidade de licenças \\
\cline { 2 - 6 } & $\mathbf{2 0 1 5}$ & $\mathbf{2 0 1 6}$ & $\mathbf{2 0 1 7}$ & $\mathbf{2 0 1 8}$ \\
\hline Algumas doenças infecciosas e parasitárias & 4.452 & 9.175 & 4.777 & 3.302 & 2.145 \\
\hline Neoplasmas (tumores) & 3.727 & 3.579 & 3.501 & 3.467 & 3.177 \\
\hline Doenças endócrinas, nutricionais e metabólicas & 1.236 & 1.202 & 1.136 & 1.027 & 840 \\
\hline Transtornos mentais e comportamentais & 40.024 & 41.817 & 44.994 & 49.166 & 52.892 \\
\hline Doenças do sistema nervoso & 3.087 & 3.037 & 3.165 & 3.155 & 2.916 \\
\hline Doenças do olho e anexos & 4.261 & 4.019 & 3.841 & 4.034 & 3.148 \\
\hline Doenças do ouvido e apófise mastoide & 1.973 & 2.171 & 1.836 & 1.756 & 1.390 \\
\hline Doenças do aparelho circulatório & 4.889 & 4.710 & 4.289 & 4.257 & 3.628 \\
\hline Doenças do aparelho respiratório & 8.778 & 9.364 & 9.679 & 9.534 & 5.343 \\
\hline Doenças do aparelho digestivo & 3.953 & 4.359 & 3.992 & 4.510 & 3.114 \\
\hline $\begin{array}{c}\text { Doenças do sistema osteomolecular e tecido } \\
\text { conjuntivo }\end{array}$ & 22.974 & 23.096 & 21.754 & 24.001 & 22.571 \\
\hline Doenças do aparelho geniturinário & 3.386 & 3.738 & 3.252 & 3.562 & 2.721 \\
\hline Gravidez, parto e puerpério & 2.135 & 2.122 & 1.880 & 1.986 & 1.466 \\
\hline $\begin{array}{c}\text { Sintomas, sinais e achados anormais de exames clínicos } \\
\text { e de laboratório, não classificados em outra parte }\end{array}$ & 2.957 & 4.045 & 3.062 & 3.431 & 2.463 \\
\hline $\begin{array}{c}\text { Lesões, envenenamentos e algumas outras } \\
\text { consequências de causas externas }\end{array}$ & 8.074 & 8.611 & 7.819 & 8.431 & 7.558 \\
\hline $\begin{array}{c}\text { Fatores que influenciam o estado de saúde e o contato } \\
\text { com os serviços de saúde }\end{array}$ & 14.980 & 15.451 & 13.693 & 13.637 & 12.254 \\
\hline Outras & 983 & 1.073 & 971 & 1.048 & 846 \\
\hline Total geral & 131.869 & 141.569 & 133.641 & 140.304 & 128.472 \\
\hline
\end{tabular}

Fonte: Elaboração própria com base em dados fornecidos pelo Departamento de Perícias Médicas do Estado de São Paulo, da Secretaria de Projetos, Orçamento e Gestão (Protocolo SIC-SP n. 406702015134) (grifos nossos). 
A partir do conjunto de motivos das licenças elencadas, verifica-se que todas reduziram suas frequências na série histórica, exceto as decorrentes de transtornos mentais e comportamentais, que, em movimento oposto, aumentaram 32\% em 4 anos. Esses dados coadunam com a análise de Assunção e Abreu (2019), ao associarem os problemas de saúde dos professores à intensificação do trabalho docente.

Os supervisores de ensino e diretores de escola compartilham a mesma estrutura de carreira, porém com vencimentos superiores aos dos docentes: em 2018, o vencimento inicial do diretor de escola era $32 \%$ maior que o do PEB I, enquanto o do supervisor de ensino era $50 \%$ superior. De forma semelhante, o PC, embora continue fazendo jus à carreira de professor, recebe gratificação específica para o exercício da função, o que equivalente a 15\% sobre a faixa 1, nível I da Escala de Vencimentos da Classe de Suporte Pedagógico.

O QAE teve instituído o Plano de Cargos, Vencimentos e Salários, em 2011, com a Lei Complementar n. 1.144 (SÃO PAULO, 2011). Além de tardia, tal lei não garantiu condições adequadas a esse segmento, pois apenas em 2018, via Decreto n. 63.471 (SÃO PAULO, 2018b), foram definidos critérios de progressão na carreira, com a previsão de avaliação de desempenho individual, a partir da autoavaliação, e de avaliação da equipe gestora, que envolve definição de objetivos e metas individuais a serem alcançadas pelo funcionário. Em 2018, o vencimento inicial do funcionário em faixa 1, nível 1 da Estrutura I correspondia a R \$ 807,79 para jornada de 40 horas semanais, estando, portanto, abaixo do salário-mínimo, que, naquele ano, correspondia a R \$ 954,00.

No rol de ações gerenciais executadas pela SEE-SP, observa-se, ainda, uma mudança na lógica orientadora da política de remuneração. A despeito dos baixos salários e dos efeitos desfavoráveis à atratividade da carreira, desde 2001 a rede implementou um sistema de pagamento por desempenho intitulado Bônus Mérito. Inicialmente, o bônus consistia em um valor pago aos profissionais da rede, uma vez ao ano, tendo como base o desempenho de estudantes no Sistema de Avaliação do Rendimento Escolar do Estado de São Paulo (Saresp), os dados de fluxo das escolas (aprovação e reprovação dos estudantes) e a assiduidade do trabalhador. A partir de 2008, com a Lei Complementar n. 1.078 (SÃO PAULO, 2008), o bônus passou a ser vinculado ao Índice de Desenvolvimento da Educação do Estado de São Paulo (Idesp) e às metas que a Secretaria da Educação estabelece para cada escola, passando a ser denominado Bonificação por Resultados. Se a lógica de retribuição financeira se assemelhava às práticas das empresas privadas, com a vinculação da bonificação às metas estipuladas externamente à escola, observa-se um refinamento dessa racionalidade, aproximando-a ainda mais de nexos gerenciais e meritocráticos.

Por fim, sobre as jornadas de trabalho na rede pública estadual paulista, supervisores, diretores, PC e servidores do QAE cumprem 40 horas semanais, mas podem ter acúmulo de cargo na mesma rede ou em rede distinta de ensino. Os professores, dada a especificidade da própria atuação, têm outras possibilidades de composição de jornada, a qual foi alterada quatro vezes no período compreendido entre 1995 a 2018.

A Lei Complementar n. 444, de 27 de dezembro de 1985 (SÃO PAULO, 1985), e o Decreto n. 24.632, de 10 de janeiro de 1986 (SÃO PAULO, 1986), estabeleceram a configuração da jornada de trabalho docente que vigorou até 1997. Nesse momento, era possível optar por Jornada Integral, de 40 horas, Completa, de 32 horas, ou, ainda, Parcial, de 20 horas. Em qualquer um dos casos, apenas $20 \%$ da carga horária era destinado ao trabalho pedagógico extraclasse.

Após a configuração da jornada de trabalho dos professores, definida pela Lei Complementar n. 836, de 30 de dezembro de 1997 (SÃO PAULO, 1997), e pelo Decreto n. 42.965, de 27 de março de 1998 (SÃO PAULO, 1998), passou-se a prever a existência apenas da Jornada Básica, com 30 horas, e da Jornada Inicial, com 24 horas. No primeiro caso, somente 5 horas eram destinadas ao trabalho pedagógico extraclasse e, no segundo caso, unicamente 4 horas, reduzindo-se, assim, não apenas as opções de jornada, mas também o percentual destinado às atividades intrínsecas ao desenvolvimento adequado do trabalho docente, que envolve preparação de aulas, correção de provas, estudos etc. Essa configuração da jornada permaneceu em vigor até 2009. 
A Lei Complementar n. 1094, de 16 de junho de 2009 (SÃO PAULO, 2009a), e o Decreto n. 55.078, de 25 de novembro de 2009 (SÃO PAULO, 2009c), alteraram novamente a jornada de trabalho docente, estabelecendo quatro diferentes configurações para vigorar a partir do ano de 2010: Integral, de 40 horas de trabalho; Básica, com 30 horas; Inicial, de 24 horas; e, por fim, criou-se a Reduzida, com apenas 12 horas de trabalho. A possibilidade de escolha da jornada reduzida sugeria que o trabalho na rede não seria a ocupação principal do docente, visto que os vencimentos para 12 horas de trabalho eram muito baixos. Para todas as jornadas, previa-se a destinação de 1/6 do tempo para trabalho extraclasse. Além disso, essa reconfiguração da jornada manteve as horas de trabalho extraclasse abaixo dos percentuais estabelecidos pela Lei n. 11.738, de 2008, que criou o Piso Salarial Profissional Nacional e definiu que $1 / 3$ da jornada docente contemplasse tempo destinado ao trabalho extraclasse (BRASIL, 2008).

Em 2012, a Resolução SE n. 8 (SÃO PAULO, 2012b) visou adequar-se à Lei n. 11.738/2008 (BRASIL, 2008) e promoveu pequenos ajustes na jornada de trabalho. Todavia, embora pequenos, esses ajustes configuraram um embuste, ao transformarem a jornada em hora, não mais em hora-aula de 50 minutos, como até aquele momento vigorava na rede. Assim, frustraram-se as expectativas da categoria, pois, efetivamente, o tempo destinado ao trabalho extraclasse não se ampliou como esperado. A Tabela 4 ilustra a composição da jornada de trabalho docente na rede pública estadual paulista desde 2012.

Tabela 4. Configuração da jornada de trabalho docente; rede estadual paulista - a partir de 2012

\begin{tabular}{ccccc}
\hline & Horas & Aulas (50 $\mathbf{~ m i n})$ & \% & \\
\hline Total & 40,0 & 48 & 100 & $1 / 1$ \\
\hline Em classe & 26,6 & 32 & 66,6 & $2 / 3$ \\
\hline Extraclasse & 13,3 & 16 & 33,3 & $1 / 3$ \\
\hline Fonte: Elaboração própria com base na Lei Complementar n. 1094, de 16 de julho de 2009 (SÃO PAULO, 2009a), no Decreto n. 55.078, de \\
25 de novembro de 2009 (SÃO PAULO, 2009c) e na Resolução SE n. 8, de 19 de janeiro de 2012 (SÃO PAULO, 2012b).
\end{tabular}

Registre-se que o desrespeito à Lei do Piso não ocorre apenas no estado de São Paulo. Em estudo nacional (JACOMINI; GIL; CASTRO, 2019) sobre o tema, constatou-se que somente dez unidades da federação cumprem adequadamente a lei. Além disso, São Paulo também não atende ao disposto na Resolução CNE/ CEB n. 2/2009, que fixou as diretrizes nacionais para os planos de carreira e remuneração dos profissionais do magistério da educação básica pública e recomenda jornadas com duração de 40 horas (BRASIL, 2009). A jornada integral é uma reivindicação antiga da categoria, pois favorece um envolvimento maior do professor com a escola e com as atividades concernentes à docência.

A SEE-SP não tem uma política de jornada integral extensiva à toda a rede. Há, de forma pontual, o Programa Ensino Integral (PEI), que, em 2018, envolvia 368 escolas, abarcando 3,68\% ${ }^{13}$ da rede, no qual os professores trabalham em jornada de 40 horas semanais e recebem $75 \%$ de gratificação sobre o vencimentobase pela dedicação exclusiva (SÃO PAULO, 2012a). Essa condição de trabalho, em termos de jornada e de remuneração, que se diferencia dos demais profissionais do magistério, é acompanhada por maior controle do trabalho docente, forte pressão para o alcance das metas do Idesp e permanente insegurança diante da permanência no programa - o qual depende de decisão do diretor e do supervisor de ensino, que tomam como base a avaliação $360^{\circ}$, ferramenta importada das empresas, que adota tanto critérios voltados à liderança quanto outros, de cunho subjetivo, gerando solicitação de transferência, para outras escolas, por parte de professores efetivos de escolas que aderem ao PEI (VENCO; MATTOS, 2019). Trata-se, assim, de forte estratégia gerencial e de controle no setor público. 
Os dados sobre jornada de trabalho docente, no entanto, pouco representam a quantidade de horas efetivamente trabalhadas pelo conjunto de professores paulistas, uma vez que somente os efetivos fazem jus às jornadas descritas anteriormente e, como abordado no artigo, o percentual de professores não efetivos na rede é significativo, variando de 40 a $60 \%$ ao longo do período analisado. A SEE-SP alegou, via SIC, não dispor de dados sobre o número de horas que integram a carga de trabalho dos professores não efetivos. Além disso, mesmo entre os professores efetivos, é comum a ampliação de jornadas de trabalho com a possibilidade legal de "carga suplementar", para o que a SEE-SP também afirmou não ter dados disponíveis a informar.

Além disso, Barbosa et al. (2021) constataram a existência de ampliação do número de horas trabalhadas pelos professores, inclusive como forma de compensar os baixos salários recebidos. No estudo, também enfatizaram a insuficiência do tempo destinado ao trabalho extraclasse na jornada docente na rede paulista, tendo em vista que a quase totalidade dos professores entrevistados declarou destinar mais tempo que o previsto em sua jornada regular de trabalho para a realização das atividades inerentes à docência.

Estudos como os realizados por Souza (2008) já apontavam a dificuldade de compreensão do tempo efetivamente trabalhado pelos professores, considerando que esse, normalmente, extrapola o tempo de ensino, compreendido como aquele dispendido em sala de aula com alunos. Essa compreensão é ainda mais limitada numa rede de ensino na qual não é possível conhecer nem mesmo o tempo que se passa em aula com os alunos, dada a impossibilidade de obtenção de dados acerca dos professores não efetivos e da carga suplementar dos professores efetivos.

Diante do fato de a SEE-SP não ter conhecimento da configuração da jornada de trabalho dos docentes sob sua incumbência, fica difícil imaginar como pode planejar políticas voltadas à melhoria das relações e condições de trabalho docente.

Não obstante as formas de contratação, designação e carreira serem fulcrais à análise da política educacional, as atribuições legais dos supervisores de ensino, dos diretores de escola e dos professores coordenadores também são indicativas de um modelo educacional calcado em resultados quantificáveis aferidos pelas avaliações externas, especialmente a partir de 2007. É possível afirmar, com base em outros estudos, a ocorrência de efetivo cerceamento da autonomia didático-pedagógica desses profissionais, impulsionado pela implantação da Proposta Curricular de São Paulo na gestão 2007-2010, cujos conteúdo e metodologia de ensino são apresentados nos Cadernos do Aluno e do Professor, produzidos sob a coordenação da SEE-SP.

O PC, explicitamente, teve, no período analisado, a supressão do termo "Pedagógico" da denominação da função, além da forma de escolha - anteriormente feita por consulta ao Conselho de Escola, após apresentação de proposta de trabalho - passou a se dar por designação com base na decisão da direção da escola e da supervisão de ensino (FERNANDES, 2018). Também as atribuições são representativas da configuração política estabelecida, voltando-se ao controle do trabalho dos professores, principalmente no que se refere ao desenvolvimento do Currículo de São Paulo, à aplicação das Avaliações de Aprendizagem em Processo ${ }^{14}$ e aos resultados obtidos nas avaliações externas das quais a escola participa.

Por fim, embora diferentes governos à frente do estado, no período analisado, tenham empreendido uma série de mudanças com a justificativa de servir à melhoria da educação, muitas voltadas à carreira, às formas de contratação, aos vencimentos e à jornada de trabalho docente, considera-se que tais mudanças foram insatisfatórias para garantir condições de trabalho adequadas. Nesse sentido, entre 1995 e 2018, no movimento dos professores, registraram-se oito greves, totalizando 275 dias de paralisação, ou seja, mais que um ano letivo. Embora tivessem pautas diversas, a reivindicação de condições dignas de trabalho, com destaque para a melhoria da remuneração, esteve presente na maioria delas, o que, no mínimo, sinaliza a existência de uma tensão entre as políticas voltadas às relações e às condições de trabalho docentes na rede e o que é vivenciado cotidianamente nas escolas. 


\section{Considerações Finais}

A análise do vasto volume de documentos e dados estatísticos sistematizados, mesmo com lacunas de registro por parte da SEE-SP, permitiu identificar a forte prevalência dos princípios gerencialistas, característicos da NGP, nas mudanças que alteraram as formas de contratação, carreira, vencimentos e jornada de trabalho dos profissionais da educação da rede pública estadual paulista.

Assim, é possível evidenciar a flexibilização nas formas de contratação e designação aos cargos de supervisor e diretor, com a permanência de parcela vultuosa de profissionais não efetivos durante todo o período e em todos os segmentos profissionais analisados.

Sobre a carreira, destaca-se que o gerencialismo é nitidamente adotado mediante a introdução de mecanismos de verificação de mérito para progressão na carreira, os quais, segundo se observou, dificultam substancialmente a progressão na carreira, com indicativos de frágeis condições para permanência, especialmente dos profissionais com pouco tempo de serviço público. Ainda que haja uma estrutura de carreira, com vários níveis e faixas, a imensa maioria dos professores encontra-se nas bordas iniciais.

Os vencimentos, por sua vez, são um dos aspectos mais contundentes para os profissionais da educação da rede paulista. No caso dos professores, estão abaixo do estabelecido pela lei federal que instituiu o PSPN, o que, compreende-se, contribui para o abandono da docência observado pelo número significativo de exonerações. Nesse cenário, a busca por funções gratificadas, a exemplo do PC, ou a atuação nas escolas do PEI passa a ser alternativa para a ampliação dos ganhos. No caso dos funcionários, isso é notado pela adesão à Gerência de Organização Escolar.

Ainda no tocante aos vencimentos, o caráter gerencial da política paulista pode ser observado no pagamento por desempenho, prática consolidada na rede pública paulista desde os anos 2000 e que, a partir de 2008, está atrelada às metas do Idesp.

A respeito da jornada de trabalho constata-se que todos os segmentos analisados cumprem jornada de 40 horas semanais, com exceção do professor, para quem é possível compô-la de outras formas. A escassez de dados oferecidos pela SEE-SP, no entanto, impede avançar nas análises. Nesse sentido, vale indagar o tratamento dos dados no estado mais rico e desenvolvido do país, o que permite ponderar que o descuido possa ser parte de um projeto de educação no qual tal elemento assume caráter secundário.

Foi possível identificar, ainda, que, embora no período imediatamente posterior a 1995 tenham sido feitas mudanças importantes na legislação - com a aprovação do Plano de Carreira, Vencimentos e Salários, por exemplo -, há uma sofisticação dos elementos gerencialistas no período compreendido entre 2007 e 2011: fragmentação da categoria docente; instituição do mérito como forma de progressão na carreira; vinculação do bônus ao Idesp; mudança nas atribuições de diretores, PC e funcionários; e diversificação da jornada de trabalho docente.

O gerencialismo parece, ainda, primar pela fragmentação em todos os aspectos da composição do trabalho na rede pública paulista, com exceção do QAE, cuja fusão de diversos cargos reduziu-se a uma única ocupação de caráter polivalente e genérico. Não obstante, se tentativas existem de enfraquecimento e desmobilização, há a possibilidade de resistência, que sempre se faz presente quando o que está em tela é o trabalho humano.

\section{Contribuição das Autoras}

Problematização e Conceitualização: Barbosa A; Jacomini MA; Fernandes MJS; Venco S; Metodologia: Barbosa A; Jacomini MA; Fernandes MJS; Venco S; Análise: Barbosa A; Jacomini MA; Fernandes MJS; Venco S; Redação: Barbosa A; Jacomini MA; Fernandes MJS; Venco S. 


\section{Notas}

1. Embora a sigla da Secretaria de Educação tenha mudado para Seduc-SP, por meio da Resolução SE n. 18/2019, neste artigo manteremos aquela utilizada nos documentos e legislações consultados: SEE-SP.

2. Dados fornecidos pela SEE-SP via SIC (Protocolo n. 53485203585) com base em informações do Censo da Educação Básica (MEC/Inep).

3. Elaboração da pesquisa com base no Censo Escolar/Inep 2018 pela equipe da pesquisa.

4. Dado fornecido pela SEE-SP via SIC (Protocolo SIC-SP n. 444191922700).

5. Dado retirado do Cadastro Funcional da Educação da SEE-SP.

6. Dado fornecido pela SEE-SP via SIC (Protocolo SIC-SP n. 546911911153).

7. Dado fornecido pela SEE-SP via SIC (Protocolo SIC-SP n. 588911912020-1).

8. Dado fornecido pela SEE-SP via SIC (Protocolo SIC-SP n. 588911912029).

9. Os rios meândricos são encontrados frequentemente nas áreas úmidas de planície. São caracterizados por curvas sinuosas e possuem um único canal, que transborda suas águas na época das cheias.

10. Embora tenhamos solicitado à Secretaria da Educação dados referentes a todo o período analisado pela pesquisa (1995 a 2018), só obtivemos dados do número de supervisores de ensino para o período de 2003 a 2018 e do número de diretores de escola para o período de 2008 a 2018.

11. Inflação acumulada calculada pelo Índice Nacional de Preços ao Consumidor (INPC).

12. Embora tenham sido solicitados dados referentes ao período de 1995 a 2018, o Departamento de Perícias Médicas só disponibilizou os dados referentes ao período de 2014 a 2018 (Protocolo SIC-SP n. 406702015134)

13. Cálculo realizado com base nos dados do Cadastro de Escolas da Secretaria Estadual de Educação. SIC n. 553741718550 .

14. São avaliações elaboradas de forma centralizada pela SEE-SP e aplicadas bimestralmente por todas as escolas, com o objetivo de acompanhar a aprendizagem dos alunos e orientar o professor na retomada de conteúdos não aprendidos.

\section{Referências}

ASSUNÇÃO, A. A.; ABREU, M. N. S. Pressão laboral, saúde e condições de trabalho dos professores da Educação Básica no Brasil. Cadernos de Saúde Pública, Rio de Janeiro, v. 35, sup. 1, p. 1-16, 2019. https:// doi.org/10.1590/0102-311X00169517

BARBOSA, A. et al. Relações e condições de trabalho dos professores paulistas (1995-2018). Cadernos de Pesquisa, São Paulo, v. 50, n. 177, p. 790-812, jul./set. 2020. https://doi.org/10.1590/198053147105

BARBOSA, A. et al. Tempo de trabalho e de ensino de professores da rede pública estadual paulista. Educação e Pesquisa, v. 47, 2021. No prelo.

BASSI, M. E.; FERNANDES, M. D. E.; ROLIM, R. M. G. (orgs.). Remuneração de professores na educação básica das redes estaduais de ensino no contexto do Fundeb e do PSPN. Curitiba: Appris, 2018. v. 1. 
BRASIL. Constituição da República Federativa do Brasil de 1988. Brasília, DF: Presidência da República, 5 out. 1988. Disponível em: http://www.planalto.gov.br/ccivil_03/constituicao/constituicao.htm. Acesso: 31 mar. 2021.

BRASIL. Plano Diretor da Reforma do Aparelho do Estado. Brasília, DF: Presidência da República, 1995. Disponível em: http://www.biblioteca.presidencia.gov.br/publicacoes-oficiais/catalogo/fhc/plano-diretor-dareforma-do-aparelho-do-estado-1995.pdf. Acesso em: 21 mar. 2021.

BRASIL. Lei n. 9.394, de 20 de dezembro de 1996. Estabelece as Diretrizes e Bases da Educação Nacional. Brasília, DF: Presidência da República, 1996. Disponível em: http://www.planalto.gov.br/ccivil_03/leis/L9394. htm. Acesso em: 27 fev. 2019.

BRASIL. Lei n. 11738, de 16 de julho de 2008. Regulamenta a alínea "e" do inciso III do caput do art. 60 do Ato das Disposições Constitucionais Transitórias, para instituir o piso salarial profissional nacional para os profissionais do magistério público da educação básica. Brasília, DF: Presidência da República, 2008. Disponível em: http://www.planalto.gov.br/ccivil_03/_ato2007-2010/2008/lei/111738.htm. Acesso em: 27 fev. 2019.

BRASIL. CNE/CEB. Resolução n. 2, de 28 de maio de 2009. Fixa as Diretrizes Nacionais para os Planos de Carreira e Remuneração dos Professores. Diário Oficial da União: seção 1, Brasília, DF, p. 41-42, 29 maio 2009. Disponível em: http://portal.mec.gov.br/dmdocuments/resolucao_cne_ceb002_2009.pdf. Acesso em: 27 fev. 2019.

CAMPOS, R. F. A formação por competências e a reforma da formação de professores/as. Teias, Rio de Janeiro, ano 5, n. 9-10, jan./dez. 2004. https://doi.org/10.12957/teias

CÁSSIO, F. L. et al. Demanda social, planejamento e direito à educação básica: uma análise da rede estadual de ensino paulista na transição 2015-2016. Educação \& Sociedade, Campinas, v. 37, p. 1089-1119, out./dez. 2016. https://doi.org/10.1590/ES0101-73302016167297

FERNANDES, M. J. S. Da articulação do trabalho coletivo ao controle do trabalho docente: os (des)caminhos legais da Coordenação Pedagógica no Estado de São Paulo. Comunicações, Piracicaba, v. 25, n. 3, p. 67-80, set./dez. 2018. https://doi.org/10.15600/2238-121X/comunicacoes.v25n3p67-80

FONTANA, C. A. Processos de admissão e condições de trabalho docente na rede pública paulista. Curitiba: CRV, 2019.

GATTI, B. A.; BARRETO, E. S. S. Professores do Brasil: impasses e desafios. Brasília: UNESCO, 2009.

GATTI, B. A. et al. A atratividade da carreira docente no Brasil. Estudos \& Pesquisas Educacionais, São Paulo, n. 1, p. 139-209, maio 2010.

HALL, D.; GUNTER, H. M. A Nova Gestão Pública na Inglaterra: a permanente instabilidade da reforma neoliberal. Educação \& Sociedade, Campinas, v. 36, n. 132, p. 743-758, jul./set. 2015. https://doi.org/10.1590/ ES0101-73302015152454

JACOMINI, M. A.; GIL, J.; CASTRO, E. C. A Lei do Piso e a Jornada: o trabalho docente nos estados. Revista Retratos da Escola, Brasília, v. 13, n. 25, p. 259-273, jan./maio 2019. https://doi.org/10.22420/rde.v13i25.918

MONLEVADE, J. A. C. Valorização salarial dos professores: o papel do Piso Salarial Profissional Nacional como instrumento de valorização dos professores da educação básica pública. 2000. Tese (Doutorado em Educação) - Faculdade de Educação, Universidade Estadual de Campinas, Campinas, 2000. 
OliVEIRA, D. A.; DUARTE, A. W. B.; CLEMENTINO, A. M. A Nova Gestão Pública no contexto escolar e os dilemas dos(as) diretores(as). Revista Brasileira de Política e Administração da Educação, Brasília, v. 33, p. 707-726, set./dez. 2017. https://doi.org/10.21573/vol33n32017.79303

PAGANI, G. Quando os professores desistem: um estudo sobre exoneração docente na rede estadual de ensino de São Paulo. 2019. 153 f. Dissertação (Mestrado em Educação Escolar) - Faculdade de Ciências e Letras, Universidade Estadual Paulista “Júlio de Mesquita Filho", Araraquara, 2019.

SANTOS, J. B. S. Professores temporários da rede estadual de São Paulo: análise da política de pessoal da perspectiva orçamentária. 2016. Dissertação (Mestrado em Educação) - Escola de Filosofia, Letras e Ciências Humanas, Universidade Federal de São Paulo, Guarulhos, 2016.

SÃO PAULO (Estado). Lei Complementar n. 444, de 27 de dezembro de 1985. Dispõe sobre o Estatuto do Magistério Paulista. São Paulo: Assembleia Legislativa do Estado de São Paulo, 1985. Disponível em: https://www.al.sp.gov.br/repositorio/legislacao/lei.complementar/1985/lei.complementar-444-27.12.1985. html\#: :text=Do\%20Estatuto\%20do\%20Magist\%C3\%A9rio\%20e,se\%2D\%C3\%A1\%20Estatuto\%20do\%20 Magist\%C3\%A9rio. Acesso em: 2 mar. 2019.

SÃO PAULO (Estado). Decreto n. 24.632, de 10 de janeiro de 1986. Regulamenta as Jornadas de Trabalho do pessoal docente do Quadro do Magistério e dá providências correlatas. São Paulo: Assembleia Legislativa do Estado de São Paulo, 1986. Disponível em: https://www.al.sp.gov.br/repositorio/legislacao/decreto/1986/ decreto-24632-10.01.1986.html. Acesso em: 19 out. 2019.

SÃO PAULO (Estado). Lei n. 7.698, de 10 de janeiro de 1992. Cria na Secretaria da Educação, o Quadro de Apoio Escolar e dá providências correlatas. São Paulo: Assembleia Legislativa do Estado de São Paulo, 1992. Disponível em: https://www.al.sp.gov.br/repositorio/legislacao/lei/1992/lei-7698-10.01.1992.html. Acesso em: 31 mar. 2021.

SÃO PAULO (Estado). Comunicado SE, de 22 de março de 1995. Diário Oficial do Estado de São Paulo, Poder Executivo, seção I, São Paulo, 23 mar. 1995.

SÃO PAULO (Estado). Lei Complementar n. 836, de 30 de dezembrode 1997. Institui Plano de Carreira, Vencimentos e Salários para os integrantes do Quadro do Magistério da Secretaria da Educação e dá outras providências correlatas. São Paulo: Assembleia Legislativa do Estado de São Paulo, 1997. Disponível em: http://www.al.sp.gov.br/repositorio/ legislacao/lei.complementar/1997/lei.complementar-836-30.12.1997.html. Acesso em: 2 mar. 2019.

SÃO PAULO (Estado). Decreto n. 42.965, de 27 de março de 1998. Dispõe sobre as jornadas de trabalho do pessoal docente do Quadro do Magistério e dá providências correlatas. São Paulo: Assembleia Legislativa do Estado de São Paulo, 1998. Disponível em: https://www.al.sp.gov.br/repositorio/legislacao/decreto/1998/ decreto-42965-27.03.1998.html. Acesso em: 19 out. 2019.

SÃO PAULO (Estado). Lei Complementar n. 888, de 28 de dezembro de 2000. Institui Plano de Carreira, Vencimentos e Salários para os integrantes do Quadro de Apoio Escolar da Secretaria da Educação e dá outras providências correlatas. São Paulo: Assembleia Legislativa do Estado de São Paulo, 2000. Disponível em: https:// www.al.sp.gov.br/repositorio/legislacao/lei.complementar/2000/original-lei.complementar-888-28.12.2000. html. Acesso em: 31 mar. 2021.

SÃO PAULO (Estado). Lei Complementar n. 1.078, de 17 de dezembro de 2008. Institui Bonificação por Resultados - BR, no âmbito da Secretaria da Educação. São Paulo: Assembleia Legislativa do Estado de São Paulo, 2008. Disponível em: https://www.al.sp.gov.br/repositorio/legislacao/lei. complementar/2008/lei.complementar-1078-17.12.2008.html. Acesso em: 10 dez. 2019. 
SÃO PAULO (Estado). Lei Complementar n. 1.094, de 16 de julho de 2009. Institui a Jornada Integral de Trabalho Docente e a Jornada Reduzida de Trabalho Docente para os integrantes do Quadro do Magistério da Secretaria da Educação, cria cargos de docente que especifica. São Paulo: Assembleia Legislativa do Estado de São Paulo, 2009a. Disponível em: https://www.al.sp.gov.br/repositorio/ legislacao/lei.complementar/2009/lei.complementar-1094-16.07.2009.html. Acesso em: 10 dez. 2019.

SÃO PAULO (Estado). Lei Complementar n. 1.097, de 27 de outubro de 2009. Institui o sistema de promoção para os integrantes do Quadro do Magistério da Secretaria da Educação. São Paulo: Assembleia Legislativa do Estado de São Paulo, 2009b. Disponível em: http://www.al.sp.gov.br/repositorio/legislacao/ lei.complementar/2009/lei.complementar-1097-27.10.2009.html. Acesso em: 2 mar. 2019.

SÃO PAULO (Estado). Decreto n. 55.078, de 25 de novembro de 2009. Dispõe sobre as jornadas de trabalho do pessoal docente do Quadro do Magistério e dá providências correlatas. São Paulo: Assembleia Legislativa do Estado de São Paulo, 2009c. Disponível em: https://www.al.sp.gov.br/ repositorio/legislacao/decreto/2009/decreto-55078-25.11.2009.html. Acesso: 23 out. 2019.

SÃO PAUlO (Estado). Lei Complementar n. 1144, de 11 de julho de 2011. Institui Plano de Cargos, Vencimentos e Salários para os integrantes do Quadro de Apoio Escolar, da Secretaria da Educação, e dá providências correlatas. São Paulo: Assembleia Legislativa do Estado de São Paulo, 2011. Disponível em: https://www.al.sp.gov.br/repositorio/legislacao/lei.complementar/2011/ lei.complementar-1144-11.07.2011.html\#: :text=Artigo\%201\%C2\%BA\%20\%2D\%20Fica\%20 institu\%C3\%ADdo\%20Plano,a\%20V\%20desta\%20lei\%20complementar. Acesso em: 31 mar. 2021.

SÃO PAULO (Estado). Lei Complementar n. 1.191, de 28 de dezembro de 2012. Dispõe sobre o Programa de Ensino Integral em escolas públicas estaduais e altera a Lei Complementar n. 1.164, de 2012, que instituiu o Regime de Dedicação Plena e Integral - RDPI e a Gratificação por Dedicação Plena e Integral - GDPI aos integrantes do Quadro do Magistério em exercício nas escolas estaduais de ensino médio de período integral, e dá providências correlatas. Diário Oficial do Estado de São Paulo, Poder Executivo, seção 1, São Paulo, p. 1, 28 dez. 2012a. Disponível em: http://www.al.sp.gov.br/repositorio/legislacao/ lei.complementar/2012/lei.complementar-1191-28.12.2012.html. Acesso: 17 maio 2019.

SÃO PAULO (Estado). Resolução SE n. 08, de 19 de janeiro de 2012. Dispõe sobre a carga horária dos docentes da rede estadual de ensino. São Paulo: Secretaria da Educação, 2012b. Disponível em: http://siau.edunet.sp.gov.br/ItemLise/arquivos/08_12.HTM. Acesso: 2 mar. 2019.

SÃO PAULO (Estado). Decreto n. 59.957, de 13 de dezembro de 2013. Reorganiza e dá nova denominação ao Banco de Cargos e Funções-Atividades Disponíveis da Administração Direta e Autárquica do Estado, de que trata o Decreto n. 40.039, de 6 de abril de 1995, e dá providências correlatas. Diário Oficial do Estado de São Paulo, Poder Executivo, seção 1, São Paulo, p. 7, 14 dez. 2013. Disponível em: https://www.al.sp.gov.br/norma/172034. Acesso em: 31 mar. 2021.

SÃO PAULO (Estado). Lei Complementar n. 1.317, de 21 de março de 2018. Dispõe sobre os vencimentos e salários dos servidores que especifica. São Paulo: Assembleia Legislativa do Estado de São Paulo, 2018a. Disponível em: https://www.al.sp.gov.br/repositorio/legislacao/lei.complementar/2018/lei.complementar-1317-21.03.2018. html. Acesso em: 10 dez. 2019.

SÃO PAULO (Estado). Decreto n. 63.471, de 11 de junho de 2018. Regulamenta a Avaliação de Desempenho Individual e estabelece os critérios relativos à Progressão para os servidores integrantes do Quadro de Apoio Escolar, prevista na Lei Complementar n. 1.144, de 11 de julho de 2011, e dá providências correlatas. São Paulo: Assembleia Legislativa do Estado de São Paulo, 2018b. Disponível em: https://www.al.sp.gov.br/repositorio/ legislacao/decreto/2018/decreto-63471-11.06.2018.html. Acesso em: 31 mar. 2021. 
SHIROMA, E. O. Gerencialismo e liderança: novos motes da gestão educacional. 2006. Mesa redonda apresentada no VI Seminário de Pesquisa em Educação na Região Sul - ANPEd Sul, Santa Maria, jun. 2006.

SOUZA, A. N. Condições de trabalho na carreira docente: comparação Brasil-França. In: SEMINÁRIO DA REDE LATINO-AMERICANA DE ESTUDOS SOBRE TRABALHO DOCENTE - REDE ESTRADO, 7, 2008, Buenos Aires. Anais [...]. Buenos Aires: Rede Estrado, 2008. 1 CD-ROM.

VENCO, S.; SANCHEZ, B. G. A precariedade em cascata: o provimento do cargo dos supervisores de ensino no estado de São Paulo. Trabalho Necessário, v. 19, n. 39, maio/ago. 2021. https://doi.org/10.22409/tn.v19i39.47765 VENCO, S.; MATTOS, R. Avaliação 360': das empresas direto às escolas de tempo integral no estado de São Paulo. Revista Brasileira de Política e Administração da Educação, Rio Grande do Sul, v. 35, n.2, 2019. https:// doi.org/10.21573/vol35n22019.95410

VERGER, A.; NORMAND, R. Nueva gestión pública y educación: elementos teóricos y conceptuales para el estúdio de un modelo de reforma educativa global. Educação \& Sociedade, Campinas, v. 36, n. 132, p. 599-622, jul./set. 2015. https://doi.org/10.1590/ES0101-73302015152799

\section{Sobre as Autoras}

Andreza Barbosa tem Licenciatura em Pedagogia pela Universidade Estadual Paulista, Mestrado em Educação pela Universidade de São Paulo e Doutorado em Educação Escolar pela Unesp. Professora do Programa de Pós-graduação em Educação da Universidade de Sorocaba. Participa do Grupo Escola Pública e Democracia.

Márcia Aparecida Jacomini é doutora em Educação pela Faculdade de Educação da Universidade de São Paulo. Professora do Departamento de Educação da Escola de Filosofia, Letras e Ciências Humanas da Universidade Federal de São Paulo. Líder do Grupo de Estudo e Pesquisa em Política Educacional e Gestão Escolar. Participa da Rede Escola Pública e Universidade.

Maria José da Silva Fernandes é doutora e mestre em Educação pelo Programa de Pós-graduação em Educação Escolar da Faculdade de Ciências e Letras da Universidade Estadual Paulista, campus Araraquara. Professora do Departamento de Educação da Faculdade de Ciências, da Unesp, campus Bauru. Professora credenciada do Programa de Pós-graduação em Educação Escolar da Faculdade de Ciências e Letras da Unesp. Líder do Grupo de Estudo e Pesquisa Trabalho Docente e suas relações com o universo escolar e a sociedade.

Selma Venco é socióloga, doutora em educação e pós-doutora em sociologia do trabalho pela Université de Paris X - Nanterre. Docente da Faculdade de Educação da Universidade Estadual de Campinas. Pesquisadora associada do Centre des Recherches Sociologiques et Politiques de Paris e vice-líder do Grupo de Estudos e Pesquisas em Política. 